Bull. Chem. Soc. Ethiop. 2021, 35(3), 659-668.

ISSN 1011-3924

(c) 2021 Chemical Society of Ethiopia and The Authors

Printed in Ethiopia

DOI: https://dx.doi.org/10.4314/bcse.v35i3.16

Online ISSN 1726-801X

\title{
AFFINITY STUDY OF $\alpha$-LACTALBUMIN NANOPARTICLES IN A MIXED SOLVENT ENVIRONMENT USING LAPLACE TRANSFORM TECHNIQUE
}

\author{
K. Kavitha and L. Palaniappan* \\ Department of Physics, Annamalai University, Chidambaram-608 002, TN, India
}

(Received July 22, 2021; Revised December 9, 2021; Accepted December 11, 2021)

\begin{abstract}
Effect of $\mathrm{pH}$ and cosolvent on the stabilization of protein structure is a well established study in protein or food science. Of the various interesting applications of protein nanoparticles, making it as a drug or bioactive compound carrier is of vital importance. This application of protein nanoparticle demands the affinity priority of protein with the available components of the medium. The basis of such studies lies in the synthesis of such protein nanoparticles and their characterizations. Secondly the knowledge of priority in affinity of protein to a particular solvent is essential. On this basis, the present work deals with the ultrasonic analysis of hydophobic interactions exhibited by the $\alpha$-lactalbumin nanoparticle synthesised by heat treatment using acetone as desolvating agent. In order to enrich the variations in hydrophobicity, $\mathrm{pH}$ and cosolvent (fructose) are included in the study. The results are compared with one of our earlier work and are interpreted in terms of the interactions existing among the components and the evolved discussions reveal that the bulk nature of the medium is controlled by the existing hydrophobicity interactions. Further, as a novel attempt, the preference of protein particle to interact with a particular solvent in mixed solvent environment is elucidated using Laplace transform technique. This approach is expected to torch light in protein science in fixing the most desirable solvent in mixed solvent environment.
\end{abstract}

KEY WORDS: $\alpha$-Lactalbumin, Fructose, Laplace Transform, Diffusion, Hydrophobic interactions

\section{INTRODUCTION}

Importance of proteins, especially the globular proteins, need not be emphasised as they are the machinery of life. They always represent the collection of the selected amino acids; differ in length and in the arrangement, from 30 to over 30,000 amino acids [1]. The ability of these life machines lies with their structural patterns, also called as folds [2]. Changes in these structural patterns, called as protein denaturation, are a very common consequence of protein additives, in particular $\mathrm{pH}$ variants. The denaturation can be controlled or even revoked by the addition of suitable cosolvent, mostly sugars. A significant globular protein, the lactalbumin in the whey of milk, is a popular biocompatible, sequence specific and soluble protein is the key substance in this study.

In addition to many studies available in literature, one of our earlier works [3] reassures the role of $\mathrm{pH}$ and cosolvent on the stability of $\alpha$-LA structure. The work cited was for $\alpha$-lactalbumin normal sized protein particles dissolved in phosphate buffer and glucose cosolvent. The present work is an extension of this earlier work.

Solubility is the most discussed parameter for selection of the protein for oral use, either as a drug or as a food. Solubility of proteins was found to be enormously enhanced by the processes in nanoparticle engineering [4]. In this approach, poor water soluble compounds are formulated as nanometre sized compound or drug particles. Arroyo-Maya et al. [5] have analyzed, adopted various techniques for the preparation of bovine $\alpha$-lactalbumin $(\alpha$-LA) nanoparticles, critically commented the relative merits and demerits and concluded that the controlling hydrophobic interactions are the basis for the various functional behaviours of $\alpha$-LA nanoparticles.

As nanoparticles of protein exhibit better solubility than their usual particles, it would be much better to analyze the effects of $\mathrm{pH}$ variants and the cosolvent on the nanoparticles rather than ordinary particles. Further, as the environment becomes mixed solvent, the priority of solvent

*Corresponding author. E-mail: lp_dde_au@yahoo.com

This work is licensed under the Creative Commons Attribution 4.0 International License 
with which the protein will interact favourably needs to be ascertained. These are the main objectives of the present work.

Thus this work has many purposes. First is to show the nano consideration offers much better solubility and stability than with the usual size protein particles. Voluminous data on denaturation studies of proteins due to $\mathrm{pH}$ variants and the support offered by the cosolvent are available in literature. However, to the best of our search, no studies were found to be done with nano protein particles. The present work deals with the production of nano sized lactalbumin particles, the effect of $\mathrm{pH}$ and cosolvent (fructose) on them by means of the relevant ultrasonic characterization studies. These characterizations offer a valid interaction picture thereby elucidating role of $\mathrm{pH}$ on denaturation and role of cosolvent on renaturation. Such techniques are highly specific as regards the bulk nature of the system and are a well established approach for the study of molecular interactions [6-9]. Further the effects of pre-treatments, $\mathrm{pH}$, additives, cosolvent etc are sharply reflected in the trend of observed ultrasonic parameters. This part of ultrasonic characterization is fully carried out as per our earlier work [3].

Secondly, this study provides a theoretical confirmation to the denaturation (due to $\mathrm{pH}$ ) and renaturation (due to cosolvent) of protein by using diffusion coefficient values. Additionally Laplace transform technique is applied on the process concerned in order to predict the priority of protein interaction with the available components of the medium. This method is found to torch light on fixing the affinity priority of the protein on the solvents available in the medium. This novel approach is an extension of another earlier work [10] that includes the formulation of a diffusive or dispersive atmosphere around the solute particle and solving the complex differential environment as an additive environment. Complete details of this procedure are given in [10] and the essence of concepts is described in a later section.

\section{EXPERIMENTAL}

All the chemicals used are AR grade, purchased from Sigma Aldrich. Powdered $\alpha$-LA from bovine milk is used for nanoparticle preparation. Nanoparticles of bovine $\alpha$-lactalbumin $(\alpha-\mathrm{LA})$ were prepared by desolvation process using acetone as desolvating agent, heat as pre-treatment (333 K for 30 minutes), cross-linkage by glutaraldehyde solution, followed by 5 cycles of centrifugation and the final product is dried as nano pellets. Size verification was carried out by dynamic light scattering (DLS) method and the hydrodynamic diameter is found to be $189.2 \mathrm{~nm}$.

Water referred in this work generally refers to double distilled water. Phosphate buffer solution is used as main solvent and fructose solution is taken as cosolvent (re-dispersion agent) for the synthesized $\alpha$-LA nanoparticle. $0.2 \mathrm{M}$ aqueous solutions of monobasic sodium phosphates (monobasic) and dibasic sodium phosphates (dibasic) were mixed in different proportions to prepare phosphate buffer of various $\mathrm{pH} v i z, \mathrm{pH} \mathrm{2,} \mathrm{5,} \mathrm{7,} 9$ and 12. Phosphoric acid or sodium hydroxide is also used as per the need. They are marked as system B whereas the system $\mathrm{B}+\mathrm{F}$ indicates the 1M solution of fructose prepared in these same phosphate buffer solutions [3].

Synthesized nano pellets were re-dispersed in the above said solvents $\mathrm{B}$ and $\mathrm{B}+\mathrm{F}$ and are respectively called as $\mathrm{B}+\mathrm{L}$ and $\mathrm{B}+\mathrm{F}+\mathrm{L}$. The $\mathrm{pH}$ of these solutions was measured by the digital $\mathrm{pH}$ meter. After preparation, the stock solution was kept stored at $293 \mathrm{~K}$ overnight. These solutions were then degassed and each measurement was made after 20 minutes of thermal equilibration $(303 \pm 0.01 \mathrm{~K})$.

\section{Measurements}

Measured parameters in the present work include ultrasound velocity $(u)$, density $(\rho)$, viscosity $(\eta)$ and surface tension $(\tau)$ whereas the calculated parameters are adiabatic compressibility $(\beta)$,

Bull. Chem. Soc. Ethiop. 2021, 35(3) 
intermolecular free length $\left(\mathrm{L}_{\mathrm{f}}\right)$, acoustic impedance $(\mathrm{z})$, relaxation time $(\mathrm{t})$, relative association constant $\left(\left(\mathrm{R}_{\mathrm{A}}\right)\right.$, the partial apparent specific volume $\left(\varphi_{\mathrm{v}}\right)$ and the partial apparent specific adiabatic compressibility $\left(\varphi_{\mathrm{k}}\right)$. Experiment was carried out at room temperature $(303 \mathrm{~K})$. In the entire study, the temperature was controlled to $\pm 0.01 \mathrm{~K}$ by water thermostatic bath provided by Ragaa Industries, Chennai, India. At least six repeated reliable observations were made for the measurement of each property and the reported values correspond to the average of these six independent measurements. The standard deviation of all the trials for each property was found to be satisfactory (not shown here).

The density $(\rho)$ of all samples was measured using $5 \mathrm{~mL}$ specific gravity bottle. The accuracy in the measurement was about $\pm 0.0001 \mathrm{kgm}^{-3}$. The ultrasonic velocity $(\mathrm{u})$ in all experimental solutions was measured by a single frequency $(2 \mathrm{MHz})$ ultrasonic interferometer (Mittal's model F-81). The accuracy of sound velocity was $\pm 0.1 \mathrm{~ms}^{-1}$. The viscosity measurements were done by relative method using Ostwald's viscometer of $10 \mathrm{~mL}$ capacity, accurate to $\pm 0.001 \mathrm{mN} \mathrm{s} \mathrm{m}^{-2}$. Surface tension values are obtained at $303 \mathrm{~K}$ by drop weight method, using platinum-irridium $\mathrm{Du}$ Nouy ring, accurate to $\pm 0.0001 \mathrm{~kg}$. Details of measurements, instruments and the procedures adopted are available in our earlier work $[11,12]$.

\section{Calculated parameters}

The chosen thermo acoustical parameters are calculated using the following standard relations [12-16]

$\beta=\left[\rho u^{2}\right]^{-1}$

$L_{f}=K_{T} \beta^{1 / 2}$

$z=u \rho$

$t=\left[\frac{4 \eta}{3 \mathrm{u}^{2} \rho}\right]$

$R_{A}=\left[\frac{\rho}{\rho_{0}}\right]\left[u_{0} / u\right]^{1 / 3}$

$\varphi_{v}=\frac{1}{\rho_{0}}+\left[\rho_{0}-\rho\right] /\left[C_{P} \rho_{0}\right]$

$\varphi_{k}=\beta_{0}\left[2 \varphi_{v}-2[u]-\frac{1}{\rho_{0}}\right]$

where $\mathrm{K}_{\mathrm{T}}$ is the temperature dependent constant having a value $199.53 \times 10^{-8}$ in SI system, $\rho_{\mathrm{o}}$ and $\rho$ are the densities, $u_{o}$ and $u$ are the ultrasonic velocities of the solvent and solution respectively, $\mathrm{C}_{\mathrm{p}}$ is the protein concentration, $\beta_{\mathrm{o}}$ is the adiabatic compressibility of the solvent and $[\mathrm{u}]$ is the relative specific sound velocity increment given as,

$[u]=\left[u-u_{0}\right] / u_{0} C_{P}$

\section{RESULTS AND DISCUSSIONS}

The measured parameters for all four systems, viz., buffer $(B)$, buffer + fructose $(B+F)$, buffer + lactalbumin $(\mathrm{B}+\mathrm{L})$ and buffer + fructose + lactalbumin $(\mathrm{B}+\mathrm{F}+\mathrm{L})$ at room temperature are summarized in Table 1, whereas Table 2 shows the calculated values of first four thermoacoustical parameters. Other calculated parameters against $\mathrm{pH}$ are depicted in Figure 1.

Table 3 shows the required basic values and the obtained values of binary diffusion coefficient or the diffusivity of protein that get in to the solvent in binary environment. Table 4 summarizes the mole fraction values of individual components in the chosen systems and the diffusion 
coefficient of protein $\left(\mathrm{D}_{\mathrm{i}, \mathrm{mix}}\right)$ in multi component environment. Figure 2 shows the amount of diffused protein in these two systems.

The perusal of Table 1 reveals that in general, the effects of solvent (buffer) as well as cosolvent (fructose) are tersely evident as specific changes are observed for almost all measured parameters. Usually the system compactness is highly reflected in the magnitudes and trends of density and sound velocity.

It is interesting to note that the addition of protein drastically reduces the density (and velocity) of buffer, means the compactness of both components got lost. However, the addition of same in buffer + fructose enhances the density (and velocity) values. This is found to be true for all $\mathrm{pH}$ values and is a clear evidence for the denaturation effect of $\mathrm{pH}$ and the renaturation effect of sugar - fructose. Same fact is again reflected in the observed trends of viscosity and surface tension. Addition of protein seems to increase viscosity values of solvent whereas addition of cosolvent decreases it. This also suggests that buffer detoriates the protein whereas fructose regain the original native state of the protein. However, as considering the surface tension parameter, addition of protein in solvent as well as cosolvent increases the magnitude. It is to be remembered that this is only at surface and in no way the inner or thorough nature of the system.

Table 1. Measured parameters at $303 \mathrm{~K}$ for the systems of buffer $(\mathrm{B})$, buffer + fructose $(\mathrm{B}+\mathrm{F})$, buffer + lactalbumin $(\mathrm{B}+\mathrm{L})$ and buffer + fructose + lactalbumin $(\mathrm{B}+\mathrm{F}+\mathrm{L})$.

\begin{tabular}{|c|c|c|c|c|c|c|c|c|}
\hline \multirow{2}{*}{$\mathrm{pH}$} & \multicolumn{2}{|c|}{$\begin{array}{c}\text { Density }(\rho) \\
\mathrm{kg} \mathrm{m}^{-3}\end{array}$} & \multicolumn{2}{|c|}{$\begin{array}{c}\text { Sound velocity }(\mathrm{u}) \\
\mathrm{m} \mathrm{s}^{-1}\end{array}$} & \multicolumn{2}{|c|}{ 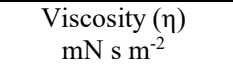 } & \multicolumn{2}{|c|}{$\begin{array}{c}\text { Surface tension }(\tau) \mathrm{N} \\
\mathrm{m}^{-1}\end{array}$} \\
\hline & $\begin{array}{c}\text { System } \\
\text { B }\end{array}$ & $\begin{array}{c}\text { System } \\
\text { B + F }\end{array}$ & $\begin{array}{c}\text { System } \\
\text { B }\end{array}$ & $\begin{array}{c}\text { System } \\
B+F\end{array}$ & $\begin{array}{c}\text { System } \\
\text { B }\end{array}$ & $\begin{array}{c}\text { System } \\
\text { B+ F }\end{array}$ & $\begin{array}{c}\text { System } \\
\text { B }\end{array}$ & $\begin{array}{c}\text { System } \\
\text { B+ F }\end{array}$ \\
\hline 2 & 1030.6 & 1081.8 & 1547.2 & 1587.8 & 0.6767 & 1.1401 & 0.2318 & 0.2468 \\
\hline 5 & 1024.1 & 1076.5 & 1549.6 & 1595.2 & 0.6532 & 1.1121 & 0.2393 & 0.2563 \\
\hline 7 & 1019.2 & 1067.5 & 1560.2 & 1591.6 & 0.7321 & 1.2872 & 0.2425 & 0.2508 \\
\hline 9 & 1023.2 & 1073.9 & 1551.0 & 1593.2 & 0.8135 & 1.2605 & 0.2573 & 0.2482 \\
\hline 12 & 1030.8 & 1084.6 & 1579.8 & 1592.4 & 0.7462 & 1.2678 & 0.2482 & 0.2431 \\
\hline & $\begin{array}{c}\text { System } \\
\text { B }+\mathrm{L}\end{array}$ & $\begin{array}{l}\text { System } \\
\text { B+F }+\mathrm{L}\end{array}$ & $\begin{array}{c}\text { System } \\
\text { B+L }\end{array}$ & $\begin{array}{l}\text { System } \\
\text { B+F +L }\end{array}$ & $\begin{array}{c}\text { System } \\
\text { B+L }\end{array}$ & $\begin{array}{l}\text { System } \\
\text { B+F +L }\end{array}$ & $\begin{array}{c}\text { System } \\
B+L\end{array}$ & $\begin{array}{l}\text { System } \\
B+F+L\end{array}$ \\
\hline 2 & 1022.6 & 1099.6 & 1526.8 & 1594.6 & 0.6911 & 0.7496 & 0.2806 & 0.2585 \\
\hline 5 & 1021.2 & 1097.3 & 1524.6 & 1593.2 & 0.6615 & 0.7251 & 0.2946 & 0.2625 \\
\hline 7 & 1018.6 & 1088.5 & 1520.6 & 1590.7 & 0.6818 & 0.7425 & 0.2875 & 0.2515 \\
\hline 9 & 1021.0 & 1096.5 & 1532.0 & 1596.4 & 0.6730 & 0.7342 & 0.2791 & 0.2421 \\
\hline 12 & 1024.7 & 1097.8 & 1537.5 & 1604.6 & 0.6816 & 0.7414 & 0.2614 & 0.2315 \\
\hline
\end{tabular}

As regards viscosity, the system of $\mathrm{B}+\mathrm{L}$ shows least magnitude whereas the $\mathrm{B}+\mathrm{F}$ has the higher compared with any other systems, irrespective of $\mathrm{pH}$. This shows that the lactalbumin nanoparticles are finely re-dispersed in the buffer that leads to aid the flow mechanism. But the suppression of the observed flow dynamics due to the addition of cosolvent may be attributed to the aggregation of nanoparticles [17]. The term aggregation here indicates the folding of protein structure and thus protein returns back to its native state by the addition of cosolvent. A lesser viscosity is a sign of greater fluidity and is an indication of fine dispersion of suspended particles or total folding of structure. Surface energy forms its basis in surface tension. Energy minimum is an excellent indication of stability [18]. In the present case, the $\mathrm{B}+\mathrm{L}$ system has a higher surface energy and in $\mathrm{B}+\mathrm{F}+\mathrm{L}$ system the same becomes the least. Thus it is again a sign of fine redispersion of nanoparticles or refolding of structure. The two factors, viz., the viscosity and the surface tension suggest that the addition of cosolvent supports the highly stable structure or particle suspension.

Table 2. Calculated parameters of adiabatic compressibility $(\beta)$, intermolecular free length $\left(\mathrm{L}_{f}\right)$, acoustic impedance $(\mathrm{Z})$ and relaxation time $(\mathrm{t})$ at $303 \mathrm{~K}$.

Bull. Chem. Soc. Ethiop. 2021, 35(3) 


\begin{tabular}{|c|c|c|c|c|c|c|c|c|}
\hline \multirow[b]{2}{*}{$\mathrm{pH}$} & \multicolumn{2}{|c|}{$\beta \times 10^{10} \mathrm{~Pa}^{-1}$} & \multicolumn{2}{|c|}{$\mathrm{L}_{\mathrm{f}} \times 10^{11} \mathrm{~m}$} & \multicolumn{2}{|c|}{$\mathrm{Z} \times 10^{-6} \mathrm{~kg} \mathrm{~m}^{-2} \mathrm{~s}^{-1}$} & \multicolumn{2}{|c|}{$\mathrm{t} \times 10^{10} \mathrm{~s}$} \\
\hline & System B & $\begin{array}{c}\text { System } \\
\text { B }+ \text { F }\end{array}$ & $\begin{array}{c}\text { System } \\
\text { B }\end{array}$ & $\begin{array}{c}\text { System } \\
\text { B }+ \text { F }\end{array}$ & $\begin{array}{c}\text { System } \\
\text { B }\end{array}$ & $\begin{array}{c}\text { System } \\
\text { B }+ \text { F }\end{array}$ & $\begin{array}{c}\text { System } \\
\text { B }\end{array}$ & $\begin{array}{c}\text { System } \\
\text { B }+ \text { F }\end{array}$ \\
\hline 2 & 4.0533 & 3.6665 & 4.0142 & 3.8178 & 1.5945 & 1.7176 & 3.6572 & 5.5736 \\
\hline 5 & 4.0664 & 3.6505 & 4.0207 & 3.8095 & 1.5869 & 1.7172 & 3.5416 & 5.4130 \\
\hline 7 & 4.0306 & 3.6979 & 4.0029 & 3.8342 & 1.5901 & 1.6990 & 3.9344 & 6.3467 \\
\hline 9 & 4.0627 & 3.6685 & 4.0188 & 3.8189 & 1.5869 & 1.7109 & 4.4066 & 6.1656 \\
\hline 12 & 3.8870 & 3.6360 & 3.9310 & 3.8019 & 1.6284 & 1.7271 & 3.8673 & 6.1463 \\
\hline & $\begin{array}{l}\text { System } \\
\mathrm{B}+\mathrm{L}\end{array}$ & $\begin{array}{l}\text { System } \\
B+F+L\end{array}$ & $\begin{array}{l}\text { System } \\
\mathrm{B}+\mathrm{L}\end{array}$ & $\begin{array}{l}\text { System } \\
\mathrm{B}+\mathrm{F}+\mathrm{L}\end{array}$ & $\begin{array}{l}\text { System } \\
\mathrm{B}+\mathrm{L}\end{array}$ & $\begin{array}{l}\text { System } \\
B+F+L\end{array}$ & $\begin{array}{l}\text { System } \\
\text { B+L }\end{array}$ & $\begin{array}{l}\text { System } \\
\mathrm{B}+\mathrm{F}+\mathrm{L}\end{array}$ \\
\hline 2 & 4.1949 & 3.5765 & 4.0837 & 3.7707 & 1.5613 & 1.7534 & 3.8655 & 3.5746 \\
\hline 5 & 4.2128 & 3.5903 & 4.0924 & 3.7780 & 1.5569 & 1.7482 & 3.7157 & 3.4711 \\
\hline 7 & 4.2458 & 3.6307 & 4.1084 & 3.7992 & 1.5488 & 1.7314 & 3.8597 & 3.5944 \\
\hline 9 & 4.1730 & 3.5785 & 4.0730 & 3.7717 & 1.5641 & 1.7504 & 3.7446 & 3.5031 \\
\hline 12 & 4.1283 & 3.5378 & 4.0511 & 3.7502 & 1.5754 & 1.7615 & 3.7518 & 3.4973 \\
\hline
\end{tabular}

In Table 2 also, in general, the effect of $\mathrm{pH}$ on the calculated parameters reflects the same tendency as in Table 1. Though the trend of magnitudes are opposite to that of in Table 1, this Table 2 also supports the weakening of interactions with rise in $\mathrm{pH}$ and strengthening of interaction due to the fructose addition. It is important to note that the $\mathrm{pH}$ extremities $(\mathrm{pH} 2$ and 12) have a sharp change in almost all measured and calculated parameters, compared to that of neutral $\mathrm{pH}$. Thus, $\mathrm{pH}$ is assured to be an agent of denaturation.

The increasing trend of compressibility and free length with $\mathrm{pH}$ reveals the weakening of the existing interactions [19]. An increasing $\beta$ simply reflects weaker interaction whereas stronger interactions are indicated by decreasing $\beta$.

The reluctance of the medium for any change is measured by the acoustic impedance property. It is again peculiar to note that $\mathrm{B}+\mathrm{L}$ system records least reluctance, means it allows any change in structure thereby supports the process of denaturation. Further in the case of $B+F+L$, the reluctance is not favoured, only reason is attributed to the nature of fructose. Thus fructose seems to behave as renaturation agent. Presence of weak interactions with a high degree of fluidity is somewhat peculiar and needs more reasoning. This can be attended by the relative parameters.

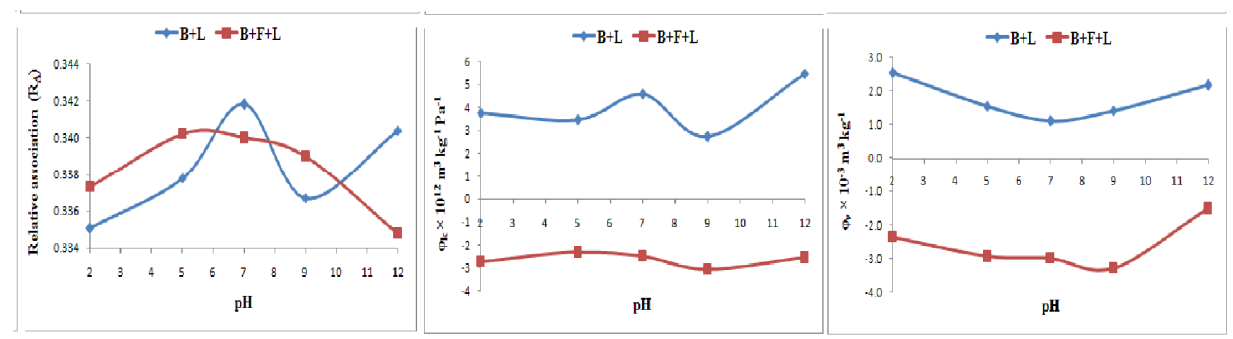

Figure 1. Trend of relative parameters.

The other three calculated parameters, called as relative parameters (Figure 1), viz., the relative association $\left(\mathrm{R}_{\mathrm{A}}\right)$, the partial apparent specific volume $\left(\varphi_{\mathrm{v}}\right)$ and the partial apparent specific adiabatic compressibility $\left(\varphi_{\mathrm{k}}\right)$, are the relative and realistic parameters that can ascertain the effect of the extra component in the systems, i.e., these parameters directly link system B+L with $\mathrm{B}+\mathrm{F}+\mathrm{L}$. 
It is a simple logic that, for the stability improvement by fructose, the inclusion of fructose to the protein should make the system to behave in such a way that it has to oppose the trend of $\mathrm{pH}$. The perusal of Figure 1, in all the three parameters, $\mathrm{pH}$ and cosolvent are found to show opposing nature to each other. Further, the change in magnitudes of respective parameters indicates that the cosolvent influences more than that of $\mathrm{pH}$ variations. This may be attributed to the fact that the particle (protein) and cosolvent (fructose), both are carbon compounds where as the buffer is inorganic in nature. Thus it is a tacit assumption that protein has a selective association with that of fructose than with buffer particles.

Always a lesser compressibility is an excellent confirmation of specific interactions. Here, $\varphi_{\mathrm{k}}$ (and $\varphi_{\mathrm{v}}$ ) values with fructose are found to be lesser than without fructose, thereby reveals that cosolvent has specific interactions. The extremely low magnitude of $\varphi_{\mathrm{k}}$ and the steric exclusion effect confirms that the existing interactions are hydrophobic [20] and are significant.

It is worth to mention that the observed trends of all the parameters considered in the present work are in line with one of our earlier work with glucose. This is attributed to the close resemblance in properties of fructose and glucose. However, the observed sharp and specific changes in the magnitudes of parameters are attributed to the nano size of the protein, thereby supports the importance of nano synthesis. Thus the interpretations of results of the present work also confirm that the $\mathrm{pH}$ extremities are sources of denaturation and sugar addition stabilizes the structure. Further, the nano particles offer a very clear and obvious interpretation of results than that of usual size particles. Simply saying, all the discussions made for the elucidation of existing interactions in glucose system of our earlier work is fit well very obviously for the present case also. Hence, the steric exclusion effect [21] as mentioned in our earlier work [12] is available in the present system, thereby confirms the existence of hydrophobic interactions.

Moreover, one assumption is also formed in this discussions that the protein has a priority for fructose than for buffer. This assumption is analyzed for its validity using the Laplace transform technique.

\section{Laplace transform technique}

Laplace transform is a technique in mathematical physics, widely used to transform a complex differential equation in to a simple algebraic equation, so as to get the exact solution in a comparatively simpler way. The chosen system in which the protein is mixed in different solvents, may be taken as the case of a solution in which the protein behaves as a solute and the other components (buffer and fructose solution) as solvent. The extent of dissolution of protein in a solvent depends on its diffusivity in the selected solvent. Based on the comments of de Wet [22, 23 ], the process of protein denaturation by $\mathrm{pH}$ variants (as well as renaturation by cosolvent) may be aptly taken as mass diffusion. Newman [24] and Jen [25] have shown that if $U$ is the concentration of a certain material in grams per cubic centimetre in a certain homogeneous medium of diffusivity constant D measured in square centimetre per second, U satisfies the equation

$$
\nabla^{2} U=\frac{1}{D} \frac{\partial U}{\partial \mathrm{t}}
$$

The solution of this equation (9) gives the calculation of the diffused mass at any instant of time t. The application of Laplace transform to this second order differential equation generates a simple algebraic equation, from which the mass transfer or the absorptivity can be calculated.

By taking proper boundary conditions, and assuming unit step function as input, using the error function and Maclaurins series for $\mathrm{e}^{-\mathrm{x}}$, the concentration of dissolved solute in a particular solvent may be obtained as

$U(\mathrm{x}, \mathrm{t})=U_{\mathrm{o}}\left\{1-\frac{2}{\sqrt{\pi}}\left(\frac{\mathrm{x}}{2 \sqrt{D t}}-\frac{(x / 2 \sqrt{D t})^{3}}{3 \mid 1}+\ldots\right)\right\}$ 
This equation reveals that, apart from the distance $\mathrm{x}$ and the time $\mathrm{t}$, diffusivity ' $\mathrm{D}$ ' is the key deciding factor for $U(x, t)$. For the determination of diffusivity, Fick's law of diffusion [26] would be a best option. But, further consideration of size, shape and nature of the molecules offer Scheibel $[27,28]$ relation as a most suitable one and it is given as

$$
\mathrm{D}_{\mathrm{AB}}=\frac{\mathrm{RT}}{\eta_{\mathrm{B}} \mathrm{V}_{\mathrm{A}}^{1 / 3}}
$$

where $\mathrm{V}_{\mathrm{A}}$ is the molar volume of solute (protein) and

$$
\mathrm{R}=8.2 \times 10^{-8}\left[1+\left(\frac{3 \mathrm{~V}_{\mathrm{B}}}{\mathrm{V}_{\mathrm{A}}}\right)^{2 / 3}\right]
$$

with a correction that if $\mathrm{V}_{\mathrm{A}}<2.5 \mathrm{~V}_{\mathrm{B}}, \mathrm{R}=17.5 \times 10^{-8}$ [28].

Equations (11) and (12) help to estimate the binary diffusivity value of solute A in solvent B. Specific gravity method and weight displacement method are used for the measurement of density of the liquid and powder samples respectively from which their molar volume was calculated. Table 3 shows the required basic values and the obtained values of binary diffusion coefficient or the diffusivity of protein that get in to the solvent in binary environment.

Table 3. Values of the density $(\rho)$, viscosity $(\eta)$ and molar volume $(V)$ of the various components of the solvent and binary diffusion coefficient $\left(\mathrm{D}_{\mathrm{AB}}\right)$ of protein $(\mathrm{A})$ in these components $(\mathrm{B})$ at $303 \mathrm{~K}$

\begin{tabular}{|l|c|c|c|r|}
\hline Solvent (B) & $\begin{array}{c}\rho \\
\mathrm{kg} \mathrm{m}^{-3}\end{array}$ & $\begin{array}{c}\eta \times 10^{3} \\
\mathrm{Nsm}^{-2}\end{array}$ & $\begin{array}{c}\mathrm{V} \times 10^{3} \\
\mathrm{~m}^{3}\end{array}$ & $\begin{array}{c}\mathrm{D}_{\mathrm{AB}} \\
\mathrm{m}^{2} \mathrm{~s}^{-1}\end{array}$ \\
\hline Water & 997.0 & 0.8903 & 0.018 & 0.09714 \\
\hline Monobasic & 1700.0 & 1.5950 & 91.765 & 0.11380 \\
\hline Dibasic & 2066.0 & 1.8611 & 68.731 & 0.09754 \\
\hline Sodium hydroxide & 2130.0 & 0.0011 & 18.777 & 181.52331 \\
\hline Phosphoric acid & 1834.0 & 3.8602 & 53.431 & 0.04702 \\
\hline Fructose & 1690.0 & 169.7872 & 106.508 & 0.00101 \\
\hline
\end{tabular}

Strictly speaking, the system taken in the present study, i.e., $\mathrm{B}+\mathrm{L}$ or $\mathrm{B}+\mathrm{F}+\mathrm{L}$, is not a binary or ternary system but a multi-component one. For multi component systems, diffusion coefficient can be best evaluated by the use of Blanc's law [29-31]. In the case of dilute component 'i' diffused in a homogeneous mixture and if $\mathrm{x}_{\mathrm{j}}$ is the mole fraction of $\mathrm{j}^{\text {th }}$ component (protein), then

$D_{i}, \operatorname{mix}=\left[\sum_{j=1}^{n} \frac{x_{j}}{D_{i j}}\right]^{-1}$

where $D_{i j}$ is the diffusivity of component $i$ into the component $j$.

Table 4 summarizes the mole fraction values of individual components in the chosen systems and the diffusion coefficient of protein $\left(D_{i, m i x}\right)$ in multi component environment. Substituting this $D_{i}$, mix values in eqn (10), amount of protein that is getting diffused per second, per unit radial distance is calculated for both systems $\mathrm{B}+\mathrm{L}$ and $\mathrm{B}+\mathrm{F}+\mathrm{L}$. The difference in these values is indicates specifically the contribution of cosolvent (fructose).

Equation (13) yields the total diffusion value of protein in the whole system and hence equation (9) gives the amount of protein diffusion in mixed solvent environment. 
Table 4. Values of the diffusion coefficient $\left(\mathrm{D}_{\mathrm{i}, \text { mix }}\right)$ of protein and amount $(\mathrm{U})$ of diffused protein at $303 \mathrm{~K}$ in the system of B + L and B + F + L

\begin{tabular}{|c|c|c|c|c|c|c|c|c|}
\hline \multirow[b]{2}{*}{$\mathrm{pH}$} & \multicolumn{6}{|c|}{ Mole fraction of } & \multirow{2}{*}{$\underset{\mathrm{m}^{2} \mathrm{~s}^{-1}}{\mathrm{Di} \text { mix }}$} & \multirow{2}{*}{$\begin{array}{c}\mathrm{U} \times 10^{6} \\
\mathrm{~kg}\end{array}$} \\
\hline & Water & Mono & Dibasic & $\begin{array}{c}\text { Phosphoric } \\
\text { acid }\end{array}$ & $\begin{array}{c}\text { Sodium } \\
\text { hydroxide }\end{array}$ & Fructose & & \\
\hline \multicolumn{9}{|c|}{ B + L System } \\
\hline 2 & 0.9967 & 0.0018 & 0.0015 & 0.000015 & - & - & 0.0972 & 11.388 \\
\hline 5 & 0.9967 & 0.0018 & 0.0015 & 0.000004 & - & - & 0.0972 & 11.388 \\
\hline 7 & 0.9967 & 0.0018 & 0.0015 & - & - & - & 0.0972 & 11.388 \\
\hline 9 & 0.9933 & 0.0016 & 0.0014 & - & 0.0037 & - & 0.0975 & 11.327 \\
\hline 12 & 0.9896 & 0.0016 & 0.0014 & - & 0.0074 & - & 0.0978 & 11.267 \\
\hline \multicolumn{9}{|c|}{ B + F + L System } \\
\hline 2 & 0.9196 & 0.0009 & 0.0007 & 0.000007 & - & 0.078822 & 0.0113 & 135.617 \\
\hline 5 & 0.9196 & 0.0009 & 0.0007 & 0.000002 & - & 0.078823 & 0.0113 & 135.617 \\
\hline 7 & 0.9196 & 0.0009 & 0.0007 & - & - & 0.078823 & 0.0113 & 135.617 \\
\hline 9 & 0.9195 & 0.0008 & 0.0006 & - & 0.001884 & 0.075374 & 0.0117 & 130.152 \\
\hline 12 & 0.9195 & 0.0008 & 0.0006 & - & 0.003762 & 0.075232 & 0.0118 & 129.888 \\
\hline
\end{tabular}

The knowledge of the protein diffusions in the two systems chosen reflects the priority of solvent, thus the one which is giving major contribution is the most affectionate solvent to protein. Hence the perusal of Table 4 reveals that $\alpha$-lactalbumin nanoparticles show maximum affinity to fructose than to buffer components. This is again a confirmation for the regaining of the lost structure by the cosolvent.

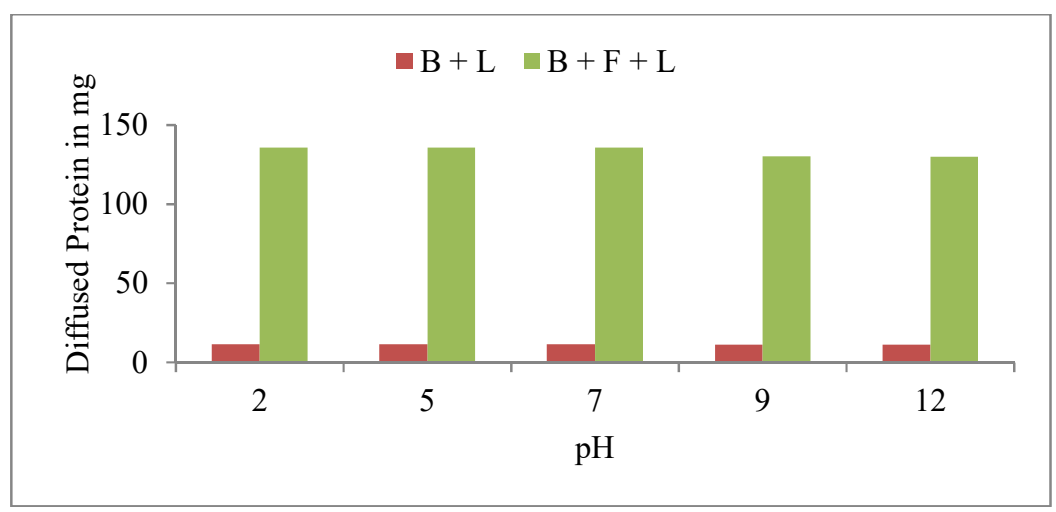

Figure 2. Amount of diffused protein at various $\mathrm{pH}$ with and without cosolvent.

Figure 2 shows the amount of diffused protein in these two systems at each $\mathrm{pH}$ and the difference in amount between these two systems specifically shows the predominant affinity of protein towards fructose. It is also evident from this Laplace transform study that the denaturation change made in protein structure is almost same irrespective of $\mathrm{pH}$ value, both acidic and basic.

\section{CONCLUSION}

The denaturation of protein $\alpha$-lactalbumin due to $\mathrm{pH}$ variants and the reversal of the same by the added cosolvent are demonstrated with fructose as cosolvent. Nano-size consideration readily reflects the consequences of $\mathrm{pH}$ and cosolvent on the protein nanoparticles. Further the application of Laplace transform is useful in estimating the contribution due to buffer and cosolvent 
quantitatively. This further helps in fixing the affinity priority of protein with the available solvents in the mixed environment.

\section{ACKNOWLEDGEMENT}

K. Kavitha hereby acknowledged with thanks the sanctioning of funds by University Research Fellowship vide Ref. No. H5/2020-2021 dated 23-01-2021 by Annamalai University, TN, India for carrying out part of this work.

\section{REFERENCES}

1. Branden, C.; Tooze, J. Introduction to Protein Structure, Garland: New York; 1991; 12.

2. Anfinsen, C.B. Principles that govern the folding of protein chains. Science 1973, 181, 223230.

3. Velusamy, V. Palaniappan, L. Effect of $\mathrm{pH}$ and glucose on the stability of $\alpha$-lactalbumin. Food Biophys. 2016, 11, 108-115.

4. Kocbek, P.; Baumgartner, S.; Kristl, J. Preparation and evaluation of nanosuspensions for enhancing the dissolution of poorly soluble drugs. Int. J. Pharm. 2006, 312, 179-186.

5. Arroyo-Maya, I.J.; Rodiles-López, J.O.; Cornejo-Mazón, M.; Gutiérrez-López, G.F.; Hernández-Arana, A.; Toledo-Núñez, C.; Barbosa-Cánovas, G.V.; Flores-Flores, J.O.; Hernández-Sánchez, H. Effect of different treatments on the ability of $\alpha$-lactalbumin to form nanoparticles. J. Dairy Sci. 2012, 95, 6204-6214.

6. Swain, S.K.; Priyadarshini, P.P. Ultrasonic and viscometric study of soya protein in aqueous solution. Indian J. Pure Appl. Phys. 2010, 48, 539-542.

7. Taulier, N.; Beletskaya, I.V.; Chalikian, T.V. Compressibility changes accompanying conformational transitions of apomyoglobin. Biopolymers 2005, 79, 218-229.

8. Palaniappan, L.; Nithyanandham, S. Molecular interactions from the experimental and validation with estimated theoretical sound velocity. Chem. Africa 2019, 3, 1-9.

9. Bahadur Alisha, K.S.; Nafeesa Banu, S.; Krishna Rao, K.S.V.; Subha, M.C.S.; Chowdoji Rao, $\mathrm{K}$. Ultrasonic studies on binary liquid mixtures of triethylamine with carbitols at $308.15 \mathrm{~K}$. Indian J. Adv. Chem. Sci. 2017, 5, 148-154.

10. Arul, G. Ultrasonic studies of some petrochemical based ternary mixtures, $\mathrm{PhD}$ dissertation, Annamalai University, Annamalainagar, Tamilnadu, India; 2008; p 383-397.

11. Palaniappan, L.; Velusamy, V. Ultrasonic study of cerebrospinal fluid. Indian J. Pure Appl. Phys. 2004, 42, 591-595.

12. Velusamy, V.; Palaniappan, L. Impact of cosolvent (glucose) on the stabilization of ovalbumin. Food Hydrocolloids 2013, 30, 217-223.

13. Velusamy, V.; Nithyanandham, S.; Palaniappan, L. Ultrasonic study of adsorption in polysaccharide metabolism. Main Group Chem. 2007, 6, 53-61.

14. Vanathi, V.; Mullainathan, S.; Nithiyanatham, S.; Ramasamy, V.; Palaniappan, L. Ultrasonic velocity, density, viscosity for the ternary mixture of (benzene + chloroform + cyclohexane) at different temperatures. Heliyon 2019, 5, e02203.

15. Ravichandran, S.; Ramanathan, K. Ultrasonic investigations of MnSo, NiSo and CuSo aqueous in polyvinyl alcohol solution at $303 \mathrm{~K}$. Rasayan J. Chem. 2010, 3, 375-384.

16. Kadi, N.E.I.; Taulier, N.; Huerou, L.; Gindre, M.; Urbach, W.; Nwigwe, I.; Kahn, P.C.; Waks, $\mathrm{M}$. Unfolding and refolding of bovine serum albumin at acid $\mathrm{pH}$ : Ultrasound and structural studies. Biophys. J. 2006, 91, 3397-3404.

17. Samuel Ebinezer, B.; Palaniappan, L. Effect of field strength in the velocity anisotropy of ferrofluids. J. Phys. Sci. 2006, 182, 1-13.

18. Burkhard Rost, Protein Structure Prediction in 1D, 2D, and 3D, 1st ed., European Molecular Biology Laboratory Publishers:, Heidelberg, Germany; 2010; p 456. 
19. Mahendran, G.; Palaniappan, L. Molecular interactions of aniline in toluene + iso-butanol system. Indian J. Pure Appl. Phys. 2011, 49, 803-808.

20. Shukla, N.; Pomarico, E.; Hecht, C.J.S.; Taylor, E.A.; Chergui, M.; Othon, C.M. Hydrophobic interactions of sucralose with protein structures. Arch. Biochem. Biophys. 2018, 639, 38-43.

21. Miyawaki, O. Hydration state change of proteins upon unfolding in sugar solutions. Biochim. Biophys. Acta 2007, 1774, 928-935.

22. de Wet, W.J.; Los Fom, J. The separation of light gaseous isotopes by mass diffusion columns. Z. Naturforschg 1964, 19a, 740-746.

23. de Wet, W.J. Perry's Chemical Engineering Handbook, 6th ed., McGraw Hill: New York; 1977; p 532

24. Newman, A.B. The drying of porous solids: Diffusion and surface emission equations. Trans. Am. Inst. Chem. Engr. 1931, 27, 203-216.

25. Liu, J.Y. A new method for separating diffusion coefficient and surface emission coefficient. Wood Fiber Sci. 1989, 21, 133-141.

26. Green, D.W.; Robert, P.H. Perry's Chemical Engineering Handbook, McGraw Hill: New York; 2008; p 545

27. Scheibel, E.G. Correspondence. Liquid diffusivities. Viscosity of gases. Ind. Eng. Chem. 1954, 46, 2007-2008.

28. Jethani, K.R. Prediction of self diffusion and infinite dilution coefficients in liquids, State University Library, Oklahoma 1985; p 221. Available at: https://core.ac.uk/download/pdf/215252396.pdf Accessed 30 May 2021.

29. Blanc, A. Recherches sur les mobilités des ions dans les gaz. J. Phys. Theor. Appl. 1908, 7, 825-839.

30. Green, D.W.; Robert, P.H. Perry's Chemical Engineering Handbook, McGraw Hill: New York; 2008; p. 553.

31. Marrero, TR.; Mason, EA. Gaseous diffusion coefficients. J. Phys. Chem. Ref. Data 1972, 1, 3-12. 